\title{
Ultraplankton distribution in surface waters of the Mozambique Channel - flow cytometry and satellite imagery
}

\author{
Mikhail V. Zubkov*, Graham D. Quartly \\ Southampton Oceanography Centre, European Way, Southampton SO14 3ZH, UK
}

\begin{abstract}
The composition of ultraplankton (UP) in near-surface samples collected underway every 1 to $6 \mathrm{~h}$ from a ship sailing from Durban to the Seychelles was determined by flow cytometry, using both autofluorescence pigments and fluorescence DNA staining. Prochlorococcus (Pro) (17 to $160 \times 10^{3}$ cells ml $\left.{ }^{-1}\right)$ numerically dominated the ultraphytoplankton (UPP), followed by Synechococcus (Syn) $\left(4.5\right.$ to $57 \times 10^{3}$ cells ml $\left.{ }^{-1}\right)$ and eukaryotic algae (EA) $\left(0.6\right.$ to $\left.4.2 \times 10^{3} \mathrm{cells} \mathrm{ml}^{-1}\right)$. The abundance of heterotrophic bacterioplankton (HB) was 0.4 to $1.3 \times 10^{6} \mathrm{cells} \mathrm{ml}^{-1}$. A strong correlation $(\mathrm{r}=0.8$ to 0.97$)$ was observed between sea-viewing wide field of view sensor (SeaWiFS) satellite estimates of total chlorophyll a (chl a) concentration and chl a concentration, abundance and biomass of EA as well as abundance and biomass of HB. This shows the potential for deducing spatial distributions of these 2 groups for ecosystem modelling using satellite data. Although the correlation between satellite chl a estimates and Syn chl a concentration was strong ( $\mathrm{r}=0.83$ to 0.88 ), the correlation with its abundance and biomass was poor $(\mathrm{r}<0.6)$ due to high variability (factor of 12$)$ in cellular chl $a$ content and to a lesser extent to diurnal cycles. The relationships were similar when either only daytime or all UP measurements were compared with the satellite data. No relationship was found between satellite data and Pro chl a concentration, abundance or biomass, even after correction for a pronounced diel cycle, suggesting that the SeaWiFS instrument might not detect Pro chl a.
\end{abstract}

KEY WORDS: Picoeukaryotic algae $\cdot$ Synechococcus $\cdot$ Prochlorococcus $\cdot$ Cyanobacteria $\cdot$ Bacterioplankton $\cdot$ Picoplankton $\cdot$ Remote sensing $\cdot$ Sea surface temperature $\cdot$ Sea surface colour $\cdot$ Chlorophyll

\section{INTRODUCTION}

Monitoring of ocean colour using satellites provides high-resolution data about the spatio-temporal distribution of photosynthetic pigments in the surface waters (Garcon et al. 2001). A valuable addition to space-based studies of primary productivity (Behrenfeld \& Falkowski 1997) would be the interpretation of these data in terms of the concentration of certain groups of abundant micro-organisms. Considering their concentrations $\left(10^{3}\right.$ to $10^{6}$ cells $\left.\mathrm{ml}^{-1}\right)$ and size (0.2 to $5 \mu \mathrm{m}$ in diameter) ultraplankton (UP) (Li 1995) should have the largest effect among organisms on light attenuation and reflection in the surface waters (Morel et al. 1993). In tropical and subtropical oceanic waters, ultraphytoplankton (UPP) account for $\sim 80 \%$ of total chlorophyll a (chl a) and phytoplankton biomass as well as for $\sim 70 \%$ of total primary production, e.g. (Li \& Harrison 2001, Maranon et al. 2001). Eukaryotic algae (EA) and cyanobacteria, the 2 main components of UPP, contribute equally to UPP biomass (Zubkov et al. 2000a). The carbon standing stock of heterotrophic bacterioplankton (HB), another component of UP, on average equals that of total phytoplankton (e.g. Li \& Harrison 2001). However, despite the apparent UP domination in tropical to equatorial oceanic waters, according to our knowledge, there have been few comparative studies of satellite measurements and in situ concentrations of UP groups. 
Using flow cytometry (Olson et al. 1993), UP can be accurately enumerated and discriminated into 3 main cytometric groups: (1) Picoeukaryotic algae; (2) cyanobacteria, i.e. Prochlorococcus (Pro) (Chisholm et al. 1988) and Synechococcus (Syn) (Waterbury et al. 1979); and (3) other nonautofluorescent HB. The latter are usually visualised by staining cellular nucleic acids with fluorescence dyes (e.g. Marie et al. 1997). Another advantage of flow cytometry is the ability to generate large sets of high quality data necessary for studying large-scale distributions of UP (e.g. Buck et al. 1996, Li 1995, Li \& Harrison 2001, Zubkov et al. 2000b). This ability is particularly useful for validating space-based biological measurements.

In the present study, we counted UP on a meridional transect along the Mozambique Channel with the aim of assessing the possibility of using satellite data for estimating the concentrations of UP groups in the surface waters.

\section{MATERIALS AND METHODS}

Sampling site. A total of 65 samples were collected from 23 to 29 August 2001 during a passage of the royal research ship RRS 'Charles Darwin' on a route from Durban (South Africa) to the Seychelle Islands (Fig. 1). The samples were collected from the ship's non-toxic seawater supply, drawn from a $5 \mathrm{~m}$ depth 10 or 11 times a day with hourly samples between 18:00 and 24:00 $\mathrm{h}$ local time and every 3 to $6 \mathrm{~h}$ during the rest

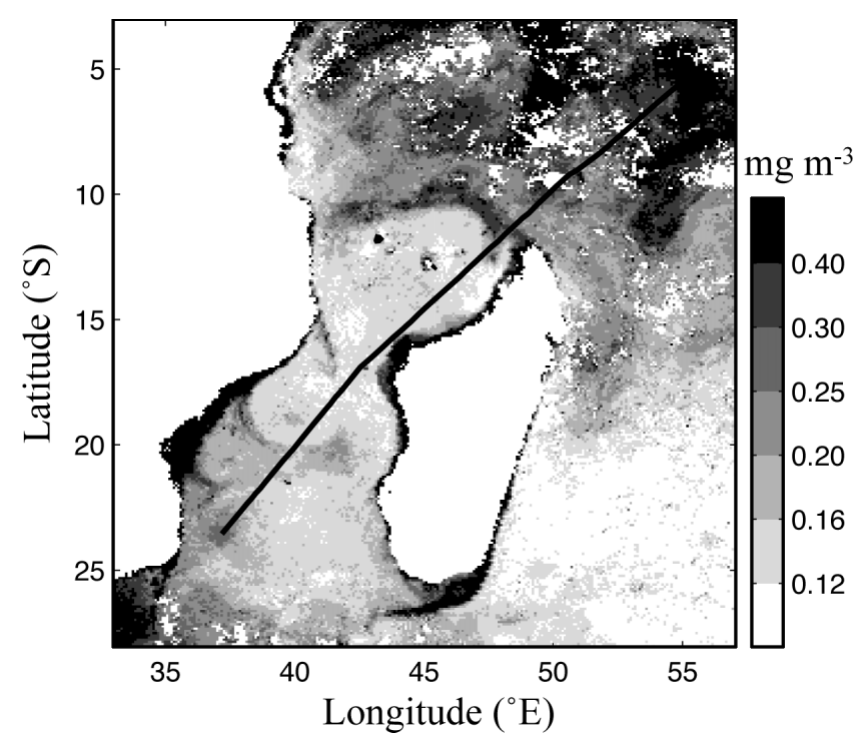

Fig. 1. Composite satellite image (SeaWiFS) of chlorophyll a spatial distribution in the Mozambique Channel from 23 to 29 August 2001, with the track of RRS 'Charles Darwin' superposed of the day. The ship's coordinates and seawater temperature were recorded at the time of sampling.

Satellite data. Two sources of satellite data were used in this study. Sea surface temperature (SST) measurements were obtained from the Tropical Rainfall Measuring Mission (TRMM) microwave imager (TMI), processed by Remote Sensing Systems. TMI is a microwave instrument, enabling SST measurements through clouds. Ocean colour data were recorded by the sea-viewing wide field of view sensor (SeaWiFS), a visible light sensor on the SeaStar platform, launched by ORBIMAGE. The sea surface was observed at $1 \mathrm{~km}$ resolution in 8 frequency bands spanning 410 to 860 $\mathrm{nm}$. Chl a concentration was determined from the radiances observed at 440, 490, 510 and $555 \mathrm{~nm}$ (O'Reilly et al. 1998), with the other channels being used in screening for clouds and correction for scattering from the atmosphere. We used the daily chl computations provided by the NASA Goddard Space Flight Centre at a resolution of $9 \mathrm{~km}$. The flow cytometric measurements were compared with both the individual satellite passes and a weekly composite (the latter improves spatial coverage, see Fig. 1).

Flow cytometry. Replicated subsamples of $1.8 \mathrm{ml}$ were taken from each collected sample, fixed with $1 \%$ paraformaldehyde (PFA), incubated at $2^{\circ} \mathrm{C}$ for $24 \mathrm{~h}$ and stored at $-20^{\circ} \mathrm{C}$ before being analysed after their return to the laboratory. UP were analysed by flow cytometry (FACSort, Becton Dickinson), using a 15 mW 488 nm laser. UPP groups, namely EA, Pro and Syn were enumerated separately on the basis of the differences in their autofluorescence properties and light scattering (Olson et al. 1993, Zubkov et al. 1998) (Fig. 2). Nonautofluorescent, predominantly HB were enumerated after staining with the DNA dye, SYBR ${ }^{\circledR}$ Green I (Marie et al. 1997). Yellow-green beads, $0.5 \mu \mathrm{m}$ in diameter (Polysciences), were used as an internal standard of $90^{\circ}$ light side-scatter as well as of red fluorescence. The ratio of the mean side-scatter or red fluorescence intensity of a UP group to the respective bead intensity was used to normalise samples and to calculate relative values of side-scatter, as an index for mean cellular biomass (Bernard et al. 2000), and red fluorescence as a substitute for mean cellular chl a content (Li 1995).

The absolute concentration of beads in a standard stock suspension was determined by flow cytometric counting of beads in volumes dispensed with an automatic micro-injector (KD Scientific). The ratio of bead abundance to that of UP groups was used to compute the absolute concentration of the latter. The concentration of HB was calculated by subtracting the Syn and Pro concentrations, determined in unstained samples from the total bacterial concentration. An estimate of total UPP chl a or biomass was a sum of the estimated 
group specific values. The latter were computed by multiplying the mean relative chl $a$ or side-scatter values on group abundance.

Because of their high degree of synchronised division, cell cycle analysis of cyanobacteria was carried out to estimate their growth rates. The stained cyanobacterial cells were discriminated from other bacteria based on their higher red fluorescence due to the presence of chl a. Larger Syn cells scattered more light than smaller Pro cells. Cyanobacterial cells with a single copy of DNA $\left(\mathrm{G}_{1}\right.$ stage) were distinguished from those in which DNA was replicating (S stage) or had already replicated $\left(\mathrm{G}_{2}\right.$ stage), and the proportion of cells at $\mathrm{S}$ and $\mathrm{G}_{2}$ stages was monitored during a diurnal cycle. The minimum growth rates of both Syn and Pro cyanobacteria were calculated according to Vaulot et al. (1995).

Data analysis. Acquisition and preliminary analysis of flow cytometric data were done using CellQuest software (Becton Dickinson). Correlation and regression analyses were used for comparison of the data sets at $99 \%$ confidence.
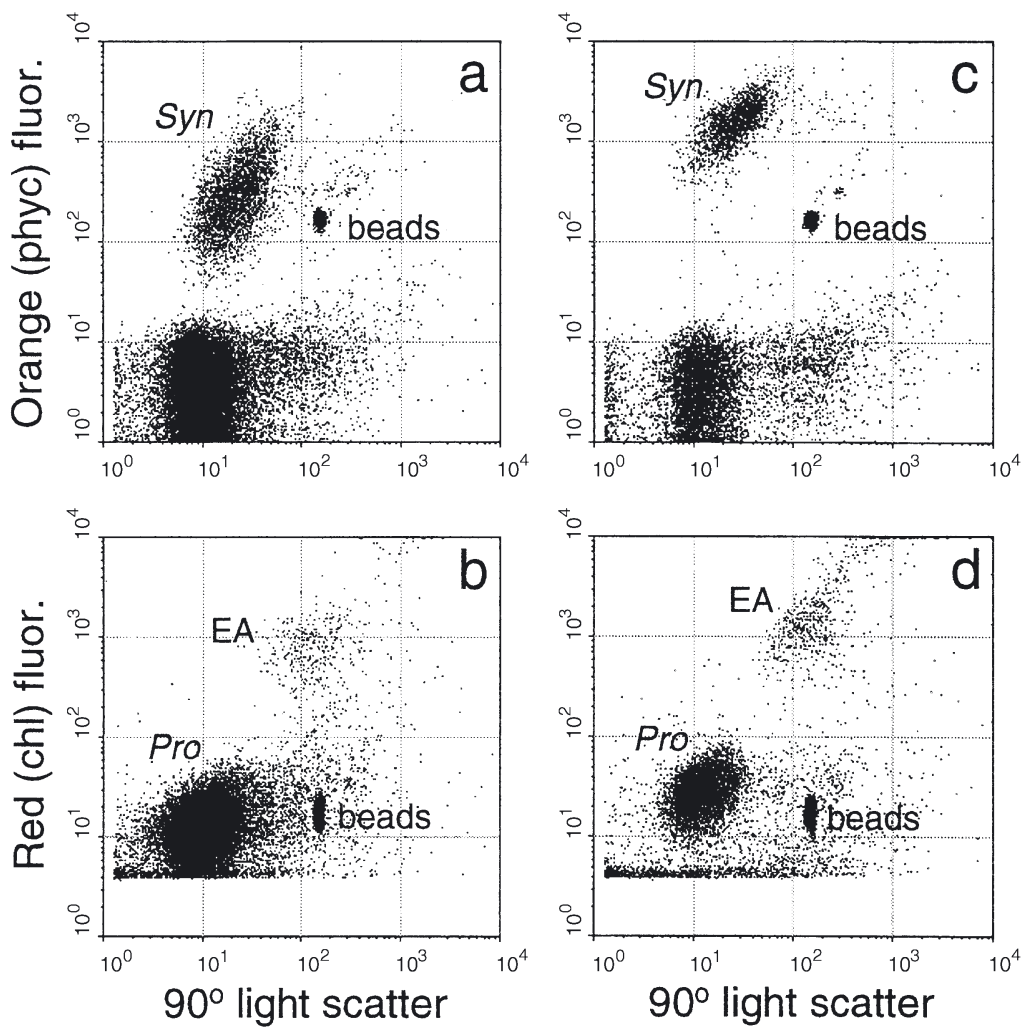

Fig. 2. Characteristic flow cytometric signatures of natural ultraphytoplankton in the $(a, b)$ Mozambique Channel and at $(c, d)$ the approaches to the Seychelles. The Synechococcus $($ Syn $)$ cluster $\left(\mathrm{a}_{1} \mathrm{c}\right)$ was revealed by its specific orange phycoerythrin (phyc) autofluorescence and excluded from the chlorophyll a (chl a) plots $(\mathrm{b}, \mathrm{d})$. The Prochlorococcus (Pro) $(\mathrm{b}, \mathrm{d})$ and eukaryotic algae (EA) (b,d) clusters were clearly resolved by their red autofluorescence of chl. Yellow-green beads, $0.5 \mu \mathrm{m}$ in diameter, were used as an internal standard

\section{RESULTS}

The SeaWiFS data revealed the derived chl a concentrations to vary on quite small spatial scales (Fig. 1). High chl a concentrations, associated with upwelling, were found along many parts of the coast of Madagascar and Mozambique. In this region, eddies and currents play an important part in the spatial distribution of the chl a signature (Quartly \& Srokosz 2003). To the south of Madagascar lies a region of high chl a waters, which have been upwelled near the coast and then entrained by the East Madagascar Current, which ws westward around the south of the island. At $20^{\circ} \mathrm{S}$ the Mozambique Channel, there is a $100 \mathrm{~km}$ wide of high chl a waters that have been advected into (hozambican coast. De Ruijter et (2002) have noted 4 to 5 anticyclonic eddies per year and along the western edge of the channel, these have on the chl a distribution. At the northern end of the channel, there is another sharp transition, presumably related to the westward-flowing North Madagascar Current entraining productive waters from the northern tip of the island.

The TMI data showed surface temperatures of around $25^{\circ} \mathrm{C}$, with values higher in the shallower regions of the central Mozambique Channel and the approach to the Seychelles $\left(55^{\circ} \mathrm{E}, 5^{\circ} \mathrm{S}\right)$. The ship and satellite records of temperature agreed closely (Fig. 3a), with a significant correlation at $p<0.0001, r=0.86$. The ship measurements, at a depth of $5 \mathrm{~m}$, were systematically $0.8^{\circ} \mathrm{C}$ lower than the satellite measurements, which correspond to the top few millimetres of the sea surface.

Encouraged by the agreement of the temperature data sets, we compared SeaWiFS chl a measurements with chl a concentration, abundance and biomass of different UP groups. Although SeaWiFS was overflying the studied area daily at about 12:00 $\mathrm{h}$ local time, SeaWiFS does not cover the entire globe in $1 \mathrm{~d}$, so there were only simultaneous satellite observations on 3 out of the $7 \mathrm{~d}$ of shipboard observations. To increase the number of comparisons with satellite measurements, we combined all satellite measurements along the ship track during the $7 \mathrm{~d}$ of onboard sampling. The mean values of chl a concentration are compared with individual observations on Fig. 3b. The coefficient of variance of mean values was rela- 

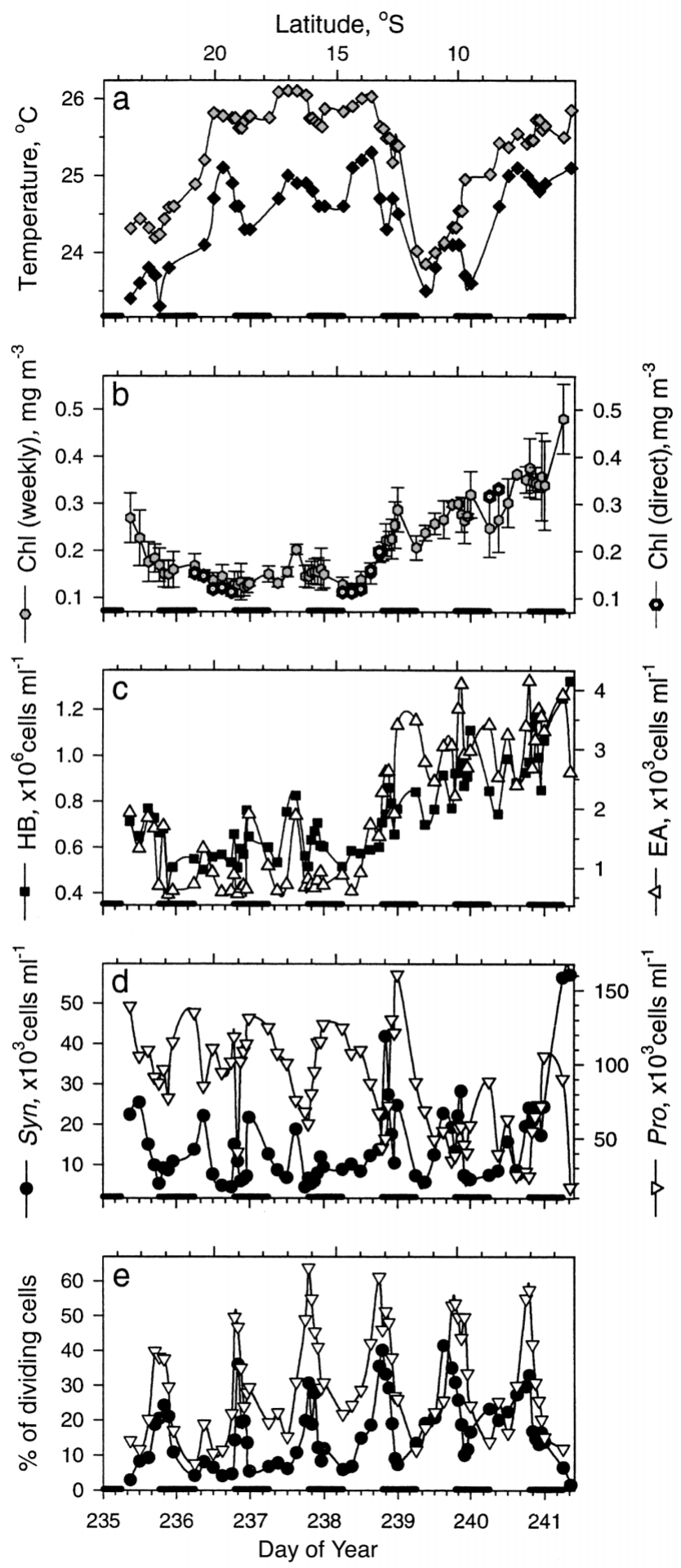

Fig. 3. (a) Latitudinal distribution of the shipboard $(\diamond)$ and satellite $(\diamond)$ sea surface temperature; (b) composite mean $(0)$ and direct $(\bullet)$ concentrations of chlorophyll a (chl a) measured by SeaWiFS satellite; error bars show single SDs; (c) heterotrophic bacteria (HB) and eukaryotic algae (EA); (d) Synechococcus (Syn) and Prochlorococcus (Pro) abundance in surface waters; and (e) temporal variation of percentages of dividing cyanobacterial cells along the ship track (symbols as in d). Thick lines at the bottom show night periods tively low (less than $30 \%$ ). To reduce the possibility of artificial relationships caused by averaging satellite data, we correlated the weekly composite as well as individual satellite chl a measurements with flow cytometric measurements of UP groups (Fig. 3, Table 1).

The direct satellite measurements (Fig. 3b, black hexagons) were compared with matched daytime (from 06:00 to 18:00 h local time) measurements of UP parameters, assuming that the ocean colour did not change during the light period (Table 1, Direct). To minimise the effect of diel variability, a subset of UP measurements recorded during the daytime was correlated with composite satellite measurements (Table 1, Daytime). Finally, the whole set of onboard UP measurements was compared with the $7 \mathrm{~d}$ satellite composite (Table 1, All). Irrespective of the analysed data set the EA and UPP chl a correlated strongly with satellite chl a measurements. A similar relationship was found for the Syn chl a, except for the comparison of the direct data sets, most likely because of a small

Table 1. Pearson correlation coefficients and their significance (given by asterisks) for the various observed relationships between the SeaWiFS chl a concentrations and flow cytometric estimates of ultraplankton group measurements, such as chl a concentrations, abundance and biomass, done between 06:00 and 18:00 $\mathrm{h}$ on the day of satellite measurement (Direct), during the daylight period (Daytime), as well as with a complete data set of the transect measurements (All). Pearson coefficients of correlation higher than 0.8 marked in bold. Difference between 2 values insignificant: $\mathrm{p}>0.01$; significant: ${ }^{*} \mathrm{p}<0.01,{ }^{* *} \mathrm{p}<0.001,{ }^{* * *} \mathrm{p}<0.0001$ (99\% CI)

\begin{tabular}{|c|c|c|c|}
\hline \multirow[t]{2}{*}{ Variables } & \multicolumn{3}{|c|}{ SeaWiFS chl a } \\
\hline & $\begin{array}{c}\text { Direct } \\
(\mathrm{n}=12)\end{array}$ & $\begin{array}{l}\text { Daytime } \\
(\mathrm{n}=30)\end{array}$ & $\begin{array}{c}\text { All } \\
(\mathrm{n}=63)\end{array}$ \\
\hline \multicolumn{4}{|l|}{ Chl a } \\
\hline Eukaryotic algae & $0.97^{* * *}$ & $0.83^{* * *}$ & $0.86^{* * *}$ \\
\hline Prochlorococcus & 0.27 & 0.03 & $0.32^{*}$ \\
\hline Synechococcus & 0.57 & $0.88^{* * *}$ & $0.85^{* * *}$ \\
\hline Total ultraphytoplankton & $0.81^{*}$ & $0.93^{* * *}$ & $0.89^{* * *}$ \\
\hline \multicolumn{4}{|l|}{ Averaged daytime chl $a$} \\
\hline Eukaryotic algae & $0.94^{* * *}$ & $0.84^{* * *}$ & $0.89^{* * *}$ \\
\hline Prochlorococcus & 0.05 & -0.03 & 0.02 \\
\hline Synechococcus & $0.85^{* *}$ & $0.84^{* * *}$ & $0.83^{* * *}$ \\
\hline Total ultraphytoplankton & $0.92^{* * *}$ & $0.89^{* * *}$ & $0.88^{* * *}$ \\
\hline \multicolumn{4}{|l|}{ Abundance } \\
\hline Eukaryotic algae & $0.93^{* * *}$ & $0.84^{* * *}$ & $0.87^{* * *}$ \\
\hline Prochlorococcus & $-0.7^{*}$ & $-0.56^{*}$ & $-0.48^{* *}$ \\
\hline Synechococcus & -0.01 & $0.67^{*}$ & $0.59^{* * *}$ \\
\hline Heterotrophic bacteria & $0.91^{* * *}$ & $0.89^{* * *}$ & $0.87^{* * *}$ \\
\hline \multicolumn{4}{|l|}{ Biomass } \\
\hline Eukaryotic algae & $0.8^{*}$ & $0.79^{* *}$ & $0.82^{* * *}$ \\
\hline Prochlorococcus & -0.57 & -0.45 & $-0.38^{*}$ \\
\hline Synechococcus & 0.11 & $0.67^{*}$ & $0.57^{* * *}$ \\
\hline Total ultraphytoplankton & -0.01 & 0.45 & $0.44^{* *}$ \\
\hline Heterotrophic bacteria & $0.92^{* * *}$ & $0.86^{* * *}$ & $0.86^{* * *}$ \\
\hline
\end{tabular}


data set combined with high variability of Syn cellular chl a content.

Each of the UPP groups comprised a substantial proportion of total UPP chl a: Syn $40 \pm 17 \%$, EA $30 \pm 9 \%$ and Pro $30 \pm 17 \%$. Therefore, the very weak correlation between the Pro chl $a$ and satellite chl a require an explanation. We plotted the satellite chl a versus the EA, EA + Syn and EA + Syn+Pro group sums, using the 3 data sets (Fig. 4). Unsurprisingly, our confidence in the slopes of the regression lines is dependent on the size of the data sets, emphasising the necessity of increasing the number of observations for more reliable regression approximations. A similar feature of all 3 plots was the parallel regression lines of the EA+Syn and EA + Syn+Pro group chl a sums that showed that the contribution of Pro chl a was similar at all stations, despite of the fact that Pro $\mathrm{chl}$ a concentration varied 6fold along the transect. Most likely, the SeaWiFS sensor could not detect Pro chl a due to the physical properties of the Pro cells (e.g. small cell size, 0.5 to $0.6 \mu \mathrm{m}$ ), which is comparable to wavelengths of visible light.

One of the sources of variability of the UPP group $\mathrm{chl} a$ is diel change in cellular chl a content (Jacquet et al. 2002). We reduced the diel effect by using only daytime cellular chl a data. For each individual day, we compared mean chl a contents of the UPP groups using only measurements taken at 09:00, 12:00 and 15:00 h local time (as the relevant satellite overpass is near 12:00 h local time), and multiplied these mean values by the concentration of cell determined during the particular day, i.e. 'averaged daytime' chl a. The diel correction increased the correlations for the EA, Syn and UPP chl a (Table 1), confirming that diel cellular chl a variation made a moderate contribution towards spatio-temporal variability of the group chl a fields. However, although Pro had the most significant diel variation, the correction had no effect on its relationship with satellite chl $a$, supporting our speculation that the satellite instrument could not detect Pro chl a.

If one decides to employ real-time satellite colour data to parameterise marine ecosystem models, the strong empirical relationships between the satellite chl $a$ and the EA and Syn chl a measurements would have limited usefulness, because additional conversion factors are required for converting the UPP group chl a estimates into the group abundance or biomass. To reduce the number of conversion steps, we looked for direct correlation between the latter 2 parameters and the satellite chl a (Table 1). Among the UP, only EA and HB group abundances have similarly strong relationship with the satellite chl a. Compared to the low variability of the EA and Pro cellular chl a contents (3 and 4.3 times, respectively), Syn cellular chl a varied 12 times, and consequently, the correlation between Syn abundance and satellite chl a was weaker than the correlation between Syn chl a and satellite chl a measurements. As Pro has its greatest abundance in oligotrophic (chl a poor) waters, it has a weak negative correlation with the satellite chl a measurements.

The satellite data would be even more useful for modelling if one could use them for approximation of
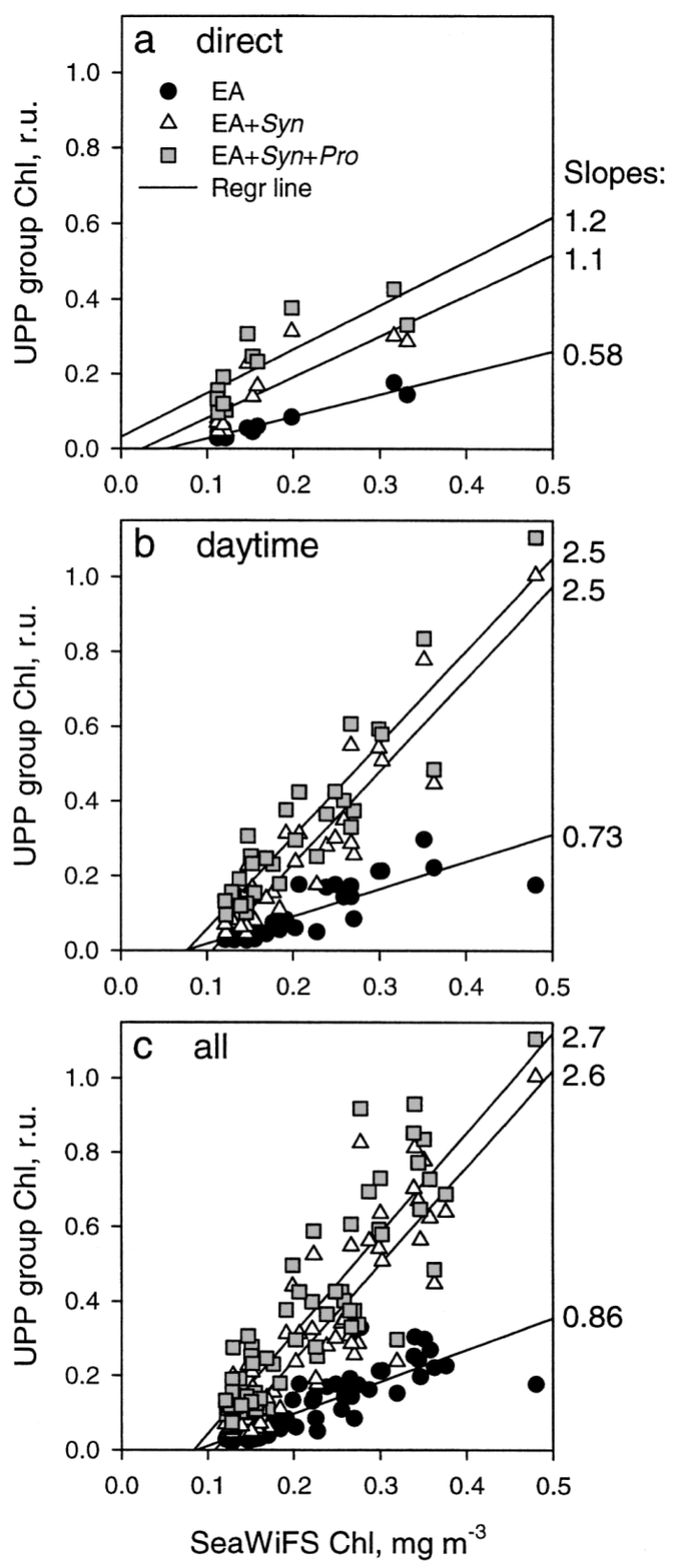

Fig. 4. Comparison of SeaWiFS chlorophyll a ( $\mathrm{chl}$ a) measurements with (a) matched/direct, (b) daytime and (c) all measurements of chl a concentrations of ultraphytoplankton (UPP) groups: eukaryotic algae (EA) plus Synechococcus (Syn) and plus Prochlorococcus (Pro) in relative units (r.u.). Lines indicate linear regressions. Corresponding slope values are shown outside the plots. See details in the text and Table 1 
the UP group biomass. In the present study, sidescatter of the UP groups was used as an index of cellular biomass. Only Pro cellular side-scatter correlated strongly with the Pro cellular chl a content $(\mathrm{r}=0.8, \mathrm{p}<$ 0.0001). However, because no significant relationship was found between satellite chl a measurements and Pro chl a concentration, there were also very weak correlation between Pro biomass and satellite chl a. Similarly to the abundance data, only the EA and HB group biomasses showed strong correlation with the satellite data.

\section{DISCUSSION}

The strong relationships found between the SeaWiFS chl a concentrations and abundance and biomass of EA and HB (Figs. 3b,c \& 4) are very encouraging, because there is a potential for estimating concentrations of these 2 groups from satellite chl a data using linear regressions. For example: EA (cells $\mathrm{ml}^{-1}$ ) = $-670 \pm 200+12000 \pm 850 \times \mathrm{chl} \mathrm{a}\left(\mathrm{ng} \mathrm{m}^{-1}\right) ; \mathrm{HB}(\mathrm{cells}$ $\left.\mathrm{ml}^{-1}\right)=320000 \pm 32000+1900000 \pm 140000 \times \mathrm{chl} a$ $\left(\mathrm{ng} \mathrm{ml} \mathrm{m}^{-1}\right.$ ). The negative intercept of the EA regression can be explained by the fact that EA represent only part of a phytoplankton community, the total chl a amount of which is determined by the satellite.

On the other hand, the satellite data used in this comparison contained no values below $0.1 \mathrm{mg} \mathrm{m}^{-3}$, whereas the cytomatric measurements at a number of stations showed minimal concentrations of EA, Syn and Pro (see Fig. 4). In general, the SeaWiFS algorithm can yield chl a concentrations below $0.05 \mathrm{mg} \mathrm{m}^{-3}$, so there would appear to be a bias in the particular satellite data set used here. This could be due to the satellite detecting chl a much deeper in the water column than the $5 \mathrm{~m}$ depth intake for the underway water supply system, or it could be due to thin undetected cloud increasing the atmospheric radiance, leading to a local bias in satellite-derived chl a values.

Higher concentration of total chl a would mean higher concentration of phytoplankton in general and EA in particular, and higher phytoplankton concentration leads to more organic nutrients for sustaining higher $\mathrm{HB}$ concentration. Using $\mathrm{EA}$ and $\mathrm{HB}$ groups (Fig. 3c) as indicators of productivity, one can speculate that the northern part of the Mozambique Channel, characterised by warmer waters (Fig. 3a), probably had lower productivity than the other traversed regions. The sharp decrease in temperature in the proximity of the northern tip of Madagascar indicated the water mass change and coincided with the increase in the EA and HB groups as well as total chl a concentrations.

Strong correlation between total chl a measurements and $\mathrm{HB}$ abundance is well documented for various aquatic systems (e.g. Simon et al. 1992). An explanation of this relationship requires an assumption of steady state for the microbial planktonic community. HB populating the open oceanic waters are dependent on phytoplankton as the ultimate source of organic nutrients, and in the studied area, the microbial community was in homeostasis. There has been considerable doubt that concentrations of unpigmented HB are likely to be approximated by remotely sensed parameters (e.g. Zubkov et al. 2002), and before generalising, we would like to check the robustness of observed relationships in other oceanic regions and during other seasons.

The abundances of Pro and Syn cyanobacteria showed a weak correlation with satellite measurements (Table 1). In the case of Syn, it was most likely due to high variability of cellular chl a content. In the case of Pro, the relationship with chl a was negative, because usually the abundance of these cyanobacteria is greater in more oligotrophic and, consequently, chl a-depleted waters (Partensky et al. 1999). Our attempts to use other SeaWiFS wave band measurements (e.g. $555 \pm 10 \mathrm{~nm}$ ) for correlating with Syn concentrations, exploiting their unique phycoerythrin orange fluorescence, were not successful.

For the required spatial coverage, the satellite images collected over a period of several days had to be composited, and consequently, the temporal resolution was sacrificed. Both EA and HB were comprised of many different species, and consequently, did not show pronounced diel cycles. Highly variable Syn and Pro abundance (Fig. 3d) were clearly controlled at an hourly scale not by nutrient sources, i.e. a 'bottom up' factor (Verity \& Smetacek 1996), but more likely by a dynamic equilibrium of synchronised replication (Vaulot et al. 1995) and mortality - predatory pressure and/or viral infection, i.e. a 'top down' factor. The primary cause of the high variability of cyanobacterial abundance was a remarkable diel synchronisation of both Syn and Pro cell division along the track (Fig. 3e) with estimated minimum growth rates of $0.25 \pm 0.037$ and $0.35 \pm 0.042 \mathrm{~d}^{-1}$ averaged for 6 full diel cycles, respectively. Up to $60 \%$ of Syn and Pro cells were generally going into division after dusk between 18:00 and 22:00 h. Similar division patterns of cyanobacteria were observed both in the Pacific (Vaulot et al. 1995) and Atlantic (Partensky et al. 1999, Zubkov et al. 2000b) Oceans, showing that this phenomenon appears to be global. The average minimum growth rate of Pro in the Mozambique Channel was about $1 / 3$ of Pro growth in the Equatorial Pacific and twice as high as estimated Pro growth in the oligotrophic Atlantic Ocean. The high diel variability seemed the most plausible explanation of the weak relationship between cyanobacterial abundance/biomass and satellite data; 
however, we were able to determine that it was not the main cause.

Thus, the present study demonstrates the utility of a combination of flow cytometry and satellite remote sensing in surveying UP. It shows both the great potential and also certain limitations of current satellite remote sensing methodology. There is a possibility of using parameters like ocean colour for predicting distribution of UP organisms like EA and even HB. New spaceborne sensors with improved spatial and spectral resolution, such as MERIS on Envisat (Rast et al. 1999), may better enable the quantification of separate pigment concentrations, and thus, classification of the different phytoplanktonic groups present. However, monitoring of cyanobacteria from space will probably remain a challenge, until satellite instrument sensitivity is significantly improved and model corrections for diel cellular pigment adaptations are established and parameterised.

Acknowledgements. We thank officers and crew aboard the RRS 'Charles Darwin' for assistance and the 2 anonymous reviewers for helpful comments on the earlier version of this paper. The authors would like to thank the SeaWiFS Project (Code 970.2) and the Distributed Active Archive Center (Code 902) at the Goddard Space Flight Center, Greenbelt, $\mathrm{MD}$, for the production and distribution of these data, respectively. These activities are sponsored by NASA's Mission to Planet Earth Program. TMI data were produced by Remote Sensing Systems and sponsored by NASA's Earth Science Information Partnerships (ESIP) and by NASA's TRMM Science Team. This work forms part of the Natural Environment Research Council (NERC) Marine and Freshwater microbial biodiversity programme (NER/T/S/2000/00635). The research of M.V.Z. was supported by an advanced research fellowship (NER/I/S/2000/00898) from NERC.

\section{LITERATURE CITED}

Behrenfeld MJ, Falkowski PG (1997) Photosynthetic rates derived from satellite-based chlorophyll concentration. Limnol Oceanogr 42:1-20

Bernard L, Courties C, Servais P, Troussellier M, Petit M, Lebaron P (2000) Relationships among bacterial cell size, productivity, and genetic diversity in aquatic environments using cell sorting and flow cytometry. Microb Ecol 40:148-158

Buck KR, Chavez FP, Campbell L (1996) Basin-wide distributions of living carbon components and the inverted trophic pyramid of the central gyre of the North Atlantic Ocean, summer 1993. Aquat Microb Ecol 10:283-298

Chisholm SW, Olson RJ, Zettler ER, Goericke R, Waterbury JB, Welschmeyer NA (1988) A novel free-living prochlorophyte abundant in the oceanic euphotic zone. Nature 334: 340-343

de Ruijter WPM, Ridderinkhof H, Lutjeharms JRE, Schouten MW, Veth C (2002) Observations of the flow in the Mozambique Channel. Geophys Res Lett 29(140):1-4

Garcon VC, Oschlies A, Doney SC, McGillicuddy D, Waniek $\mathrm{J}$ (2001) The role of mesoscale variability on plankton dynamics in the North Atlantic. Deep-Sea Res II 48: $2199-2226$

Jacquet S, Prieur L, Avois-Jacquet C, Lennon JF, Vaulot D
(2002) Short-timescale variability of picophytoplankton abundance and cellular parameters in surface waters of the Alboran Sea (western Mediterranean). J Plankton Res 24:635-651

Li WKW (1995) Composition of ultraphytoplankton in the central North Atlantic. Mar Ecol Prog Ser 122:1-8

Li WKW, Harrison WG (2001) Chlorophyll, bacteria and picophytoplankton in ecological provinces of the North Atlantic. Deep-Sea Res II 48:2271-2293

Maranon E, Holligan PM, Barciela R, Gonzalez N, Mourino B, Pazo MJ, Varela M (2001) Patterns of phytoplankton size structure and productivity in contrasting open-ocean environments. Mar Ecol Prog Ser 216:43-56

Marie D, Partensky F, Jacquet S, Vaulot D (1997) Enumeration and cell cycle analysis of natural populations of marine picoplankton by flow cytometry using the nucleic acid stain SYBR Green I. Appl Environ Microbiol 63:186-193

Morel A, Ahn YH, Partensky F, Vaulot D, Claustre H (1993) Prochlorococcus and Synechococcus: A comparative study of their optical properties in relation to their size and pigmentation. J Mar Res 51:617-649

Olson RJ, Zettler ER, DuRand MD (1993) Phytoplankton analysis using flow cytometry. In: Kemp PF, Sherr BF, Sherr EB, Cole JJ (eds) Handbook of methods in aquatic microbial ecology. Lewis Publishers, Boca Raton, FL, p 175-186

O'Reilly JE, Maritorena S, Mitchell BG, Siegel DA, Carder KL, Garver SA, Kahru M, McClain C (1998) Ocean color chlorophyll algorithms for SeaWiFS. J Geophys Res C 103:24937-24953

Partensky F, Hess WR, Vaulot D (1999) Prochlorococcus, a marine photosynthetic prokaryote of global significance. Microbiol Mol Biol Rev 63:106-127

Quartly GD, Srokosz MA (2003) Eddies in the southern Mozambique Channel. Deep-Sea Res II (in press)

Rast M, Bezy JL, Bruzzi S (1999) The ESA Medium Resolution Imaging Spectrometer MERIS - a review of the instrument and its mission. Int J Remote Sens 20:1681-1702

Simon M, Cho BC, Azam F (1992) Significance of bacterial biomass in lakes and the ocean-comparison to phytoplankton biomass and biogeochemical implications. Mar Ecol Prog Ser 86:103-110

Vaulot D, Marie D, Olson RJ, Chisholm SW (1995) Growth of Prochlorococcus, a photosynthetic prokaryote, in the equatorial Pacific ocean. Science 268:1480-1482

Verity PG, Smetacek V (1996) Organism life cycles, predation, and the structure of marine pelagic ecosystems. Mar Ecol Prog Ser 130:277-293

Waterbury JB, Watson SW, Guillard RRL, Brand LE (1979) Wide-spread occurrence of a unicellular, marine planktonic, cyanobacterium. Nature 277:293-294

Zubkov MV, Sleigh MA, Tarran GA, Burkill PH, Leakey RJG (1998) Picoplanktonic community structure on an Atlantic transect from 50 degrees $\mathrm{N}$ to 50 degrees S. Deep-Sea Res I 45:1339-1355

Zubkov MV, Sleigh MA, Burkill PH, Leakey RJG (2000a) Picoplankton community structure on the Atlantic Meridional Transect: a comparison between seasons. Prog Oceanogr 45:369-386

Zubkov MV, Sleigh MA, Burkill PH (2000b) Assaying picoplankton distribution by flow cytometry of underway samples collected along a meridional transect across the Atlantic Ocean. Aquat Microb Ecol 21:13-20

Zubkov MV, Fuchs BM, Tarran GA, Burkill PH, Amann R (2002) Mesoscale distribution of dominant bacterioplankton groups in the northern North Sea in early summer. Aquat Microb Ecol 29:135-144 